\title{
Venom from Bothrops lanceolatus, a Snake Species Native to Martinique, Potently Activates the Complement System
}

\author{
Marie Delafontaine, ${ }^{1,2}$ Isadora Maria Villas-Boas, ${ }^{1}$ Giselle Pidde, ${ }^{1}$ Carmen W. van den Berg, ${ }^{3}$ \\ Laurence Mathieu, ${ }^{2}$ Joël Blomet, ${ }^{2}$ and Denise V. Tambourgi ${ }^{1}{ }^{1}$ \\ ${ }^{1}$ Immunochemistry Laboratory, Butantan Institute, Av. Prof. Vital Brazil 1500, 05503-900 São Paulo, SP, Brazil \\ ${ }^{2}$ Prevor Laboratory, Moulin de Verville, 95760 Valmondois, France \\ ${ }^{3}$ Centre for Medical Education, Cardiff University, School of Medicine, Cardiff CF144XN, UK
}

Correspondence should be addressed to Denise V. Tambourgi; denise.tambourgi@butantan.gov.br

Received 14 December 2017; Accepted 30 May 2018; Published 15 July 2018

Academic Editor: Enrique Ortega

Copyright ( 2018 Marie Delafontaine et al. This is an open access article distributed under the Creative Commons Attribution License, which permits unrestricted use, distribution, and reproduction in any medium, provided the original work is properly cited.

\begin{abstract}
Bothrops lanceolatus snake venom causes systemic thrombotic syndrome but also local inflammation involving extensive oedema, pain, and haemorrhage. Systemic thrombotic syndrome may lead to fatal pulmonary embolism and myocardial and cerebral infarction. Here, we investigated the ability of B. lanceolatus venom to activate the Complement system (C) in order to improve the understanding of venom-induced local inflammation. Data presented show that B. lanceolatus venom is able to activate all C-pathways. In human serum, the venom strongly induced the generation of anaphylatoxins, such as C5a and C4a, and the Terminal Complement complex. The venom also induced cleavage of purified human components C3, C4, and C5, with the production of biologically active $\mathrm{C} 5 \mathrm{a}$. Furthermore, the venom enzymatically inactivated the soluble C-regulator and the $\mathrm{C} 1$-inhibitor (C1-INH), and significantly increased the expression of bound C-regulators, such as MCP and CD59, on the endothelial cell membrane. Our observations that $B$. lanceolatus venom activates the three Complement activation pathways, resulting in anaphylatoxins generation, may suggest that this could play an important role in local inflammatory reaction and systemic thrombosis caused by the venom. Inactivation of $\mathrm{C} 1-\mathrm{INH}$, which is also an important inhibitor of several coagulation proteins, may also contribute to inflammation and thrombosis. Thus, further in vivo studies may support the idea that therapeutic management of systemic B. lanceolatus envenomation could include the use of Complement inhibitors as adjunct therapy.
\end{abstract}

\section{Introduction}

Snakes from the genus Bothrops are responsible for the majority of venomous ophidian accidents in South and Central America [1]. They induce a complex pathophysiology, referred to as bothropic syndrome. After envenomation, haemorrhage, pain, and oedema appear quickly at the site of the bite, whereas coagulation disturbances, haemorrhage, and renal failure are commonly observed systemic symptoms [2]. Dermonecrosis, myonecrosis, and local infection can cause disabling sequels $[3,4]$.

Bothrops lanceolatus, commonly named Martinique lancehead ("Fer-de-lance"), is a native species confined to the Caribbean island of Martinique. Systemic clinical symptoms of $B$. lanceolatus envenomation differ from envenomation by other Bothrops species as it is characterized by a predominant prothrombotic profile and is rarely haemorrhagic [2]. In approximately $30-40 \%$ of the cases, multiple arterial thrombi occur, which is unique to $B$. lanceolatus and B. carribeus, a Bothrops species from the neighbouring island of Saint Lucia. This can lead to death due to myocardial and cerebral infarction or pulmonary oedema [5]. Local effects are comparable to the bothropic syndrome involving prominent oedema, pain, and haemorrhage from the fang marks. In case of envenomation, only rapid treatment with the monospecific commercial antivenom, raised against $B$. lanceolatus venom (Bothrofav ${ }^{\circledR}$, Sanofi Pasteur, France), can prevent the development of 
systemic thrombosis, which if untreated can result in death $[5,6]$. But even this antivenom is not always effective and supplementary therapies may be beneficial to the patient [6]. Thus, a better understanding of how this venom causes pathology is required.

Bothrops snake venoms are complex mixtures of bioactive organic and inorganic components, such as proteins, peptides, carbohydrates, lipids, and mineral salts. These venoms display a wide range of interspecies variations both in composition and biological activities [7-12]. Metalloand serine proteases are among the most abundant enzymes found in Bothrops venoms. They play a central part in the local and systemic development of the pathophysiology of envenomation, respectively, by inducing haemorrhage, myonecrosis, inflammation, cutaneous lesions, and haemostasis disturbances [12-15].

The Complement (C) system, a complex group of more than 50 blood-circulating and cell-surface-expressed and intracellular proteins, is an important effector mechanism of innate and adaptive immunity [16]. Amplification of the inflammatory response, phagocytosis, lysis of pathogenic agents, and recognition of altered self are a few of the biological processes in which the Complement system is involved [17-20]. Once activated, a chain reaction of proteolysis and assembly of protein complexes evolves, which is finely regulated by soluble and membrane-bound regulators [21]. Complement activation can be initiated through any of its three activation pathways: classical (CP), alternative (AP), or lectin (LP), all converging towards the formation of C3convertases and the cleavage of $\mathrm{C} 3$ component into $\mathrm{C} 3 \mathrm{~b}$ and the anaphylatoxin $\mathrm{C} 3 \mathrm{a} . \mathrm{C} 3 \mathrm{~b}$ is involved in the formation of the C5-convertase, which in turns cleaves $\mathrm{C} 5$ into $\mathrm{C} 5 \mathrm{~b}$ and the anaphylatoxin $\mathrm{C} 5 \mathrm{a}$. C5b interacts with $\mathrm{C} 6, \mathrm{C} 7, \mathrm{C} 8$, and several C9 proteins to form the membrane attack complex (C5b-9 or MAC), which generates a lytic pore in the target membrane. The anaphylatoxins $\mathrm{C} 3 \mathrm{a}, \mathrm{C} 4 \mathrm{a}$, and $\mathrm{C} 5 \mathrm{a}$ constitute potent proinflammatory mediators, via the interaction with specific receptors such as $\mathrm{C} 3 \mathrm{aR}$ and $\mathrm{C} 5 \mathrm{aR} 1$ [22]. The activation of the Complement cascade is regulated by membrane proteins including Complement-receptor 1 (CR1), membrane cofactor protein (MCP/CD46), decay-accelerating factor (DAF/CD55), and CD59. Factor I, Factor H, Factor-H related proteins, C4-binding protein (C4BP), and $\mathrm{C1}$ inhibitor (C1-INH) are important soluble regulators of Complement [23-26].

Inappropriate activation of the Complement cascade can be harmful to the host and can lead to inflammation and thrombosis [27]. Numerous animal venoms interact with the human Complement system, for example, by initiating the C-cascade activation, as shown for venoms of 19 different Bothrops species from South and Central America [28, 29]. In these studies, we showed that Bothrops venoms triggered the C-cascade by one or several activation pathways, generating high quantities of anaphylatoxins by directly cleaving C3 and $\mathrm{C} 5$ or by inactivating the regulator $\mathrm{C} 1-\mathrm{INH}$. These events involved both metalloproteases and serine proteases. No modifications of the membrane regulators, DAF, CR1, and CD59, were observed in case of Bothrops venoms exposure [28, 30-32]. The activation of the Complement system by Bothrops venoms may constitute an important event in human bothropic envenomation pathophysiology.

$B$. lanceolatus venom is antigenically similar to other Bothrops venoms but differs from other Bothrops venoms in that it does not induce coagulation of human plasma, has very low hyaluronidase activity, and their proteases have different substrate specificities [10,33]. The B. lanceolatus venom contains glycosylated proteins that could potentially trigger the lectin Complement pathway [10,34]. Considering that the anti- $B$. lanceolatus antivenom Bothrofav is not always $100 \%$ percent effective at preventing local and systemic events [6], supplementary therapies may be beneficial to the patient. Thus, a better understanding of how this venom causes inflammation and thrombosis is required. Considering the important role Complement can play in inflammation and thrombosis, we investigated the potential of $B$. lanceolatus to activate the Complement cascade in vitro, and interact with its proteins, regulators, and receptors. Here, we show that $B$. lanceolatus venom activates Complement cascade, affecting major C-components and soluble/membrane-bound inhibitors, and inducing the production of proinflammatory mediators.

\section{Material and Methods}

2.1. Chemicals, Reagents, and Buffers. Tween-20, Dextran 70, ethylene diamine tetraacetic acid (EDTA), ethylene glycol-bis-(beta-aminoethylether)- $\mathrm{N}, \mathrm{N}, \mathrm{N}^{\prime}, \mathrm{N}^{\prime}$-tetraacetic acid (EGTA), barbituric acid, sodium barbital, ortho-phenylenediamine (OPD), phenylmethanesulfonyl fluoride (PMSF), 1,10-phenantroline, mannan, and bovine serum albumin (BSA) were purchased from Sigma-Aldrich (St. Louis, MO, USA). Purified human Complement components C3, C4, C5, and C1-INH, as well as goat anti-human C4 antibody were purchased from Quidel Corporation (San Diego, CA, USA). Fluo-4 AM was from Life Technologies (Waltham, MA, USA). The following murine antibodies against human CD46 (clone E4.3), CD55 (clone IA10), and CD59 (clone p282-H19) were purchased from BD Pharmingen (San Diego, CA, USA). Polyclonal goat antimouse IgG-PE, polyclonal rabbit anti-goat IgG labelled with alkaline phosphatase, and goat anti-human C1-INH antibodies were obtained from Sigma-Aldrich (MO, USA). Foetal bovine serum (FBS) was from Cultilab (São Paulo, Brazil). Dulbecco's modified Eagle's medium (DMEM), penicillin, and streptomycin were from Gibco/Thermo Fisher Scientific (Gaithersburg, MD, USA). Buffers include saline solution $(150 \mathrm{mM} \mathrm{NaCl}), \mathrm{PBS}\left(8.1 \mathrm{Mm} \mathrm{Na}{ }_{2} \mathrm{HPO}_{4}\right.$, $1.5 \mathrm{mM} \mathrm{KH}_{2} \mathrm{PO}_{4}, 137 \mathrm{mM} \mathrm{NaCl}$, and $2.7 \mathrm{mM} \mathrm{KCl}, \mathrm{pH} 7.2$ ), Alsever's solution ( $114 \mathrm{mM}$ citrate, $27 \mathrm{mM}$ glucose, $72 \mathrm{mM}$, and $\mathrm{NaCl}, \mathrm{pH} 6.1$ ), Veronal-Buffered Saline $\left(\mathrm{VBS}^{2+} ; 2.8 \mathrm{mM}\right.$ barbituric acid, $145.5 \mathrm{mM} \mathrm{NaCl}$, and $0.3 \mathrm{mM} \mathrm{CaCl}_{2}$, $\mathrm{pH}$ 7.2), AP buffer (5 mM sodium barbital, $7 \mathrm{mM} \mathrm{MgCl}_{2}$, $10 \mathrm{mM}$ EGTA, and $150 \mathrm{mM} \mathrm{NaCl}, \mathrm{pH} 7.4), \mathrm{BVB}^{2+}$ buffer $\left(\mathrm{VBS}^{2+}, 0.5 \mathrm{mM} \mathrm{MgCl} 2,2 \mathrm{mM} \mathrm{CaCl}{ }_{2}, 0.05 \%\right.$ Tween-20, and $0.1 \%$ BSA, pH 7.5), BSS buffer $(137 \mathrm{mM} \mathrm{NaCl}$, $2.68 \mathrm{mM} \mathrm{KCl}, 78.3 \mathrm{mM} \mathrm{Na}_{2} \mathrm{HPO}_{4}$, and $1.47 \mathrm{mM} \mathrm{KH}_{2} \mathrm{PO}_{4}$ ), Krebs buffer (120 mM NaCl, $25 \mathrm{mM}$ HEPES, $4.8 \mathrm{mM} \mathrm{KCl}$, 
$1.2 \mathrm{mM} \mathrm{KH}_{2} \mathrm{PO}_{4}$, and $1.2 \mathrm{mM} \mathrm{MgSO}$ ), and FACS buffer (1\% BSA, $0.01 \% \mathrm{NaN}_{3}$ in PBS).

2.2. Venom. Venom from Bothrops lanceolatus (B. lanceolatus) was obtained from Latoxan (Aix-en-Provence, France). Stock solution was prepared in sterile saline solution at $5 \mathrm{mg} / \mathrm{mL}$ and stored at $-80^{\circ} \mathrm{C}$.

2.3. Normal Human Serum, Erythrocytes, and Ethics Statements. Human blood was obtained by signed consent from healthy donors. Blood was collected by venepuncture without anticoagulant and refrigerated for $4 \mathrm{~h}$. After clot formation, blood was centrifuged at $400 \times \mathrm{g}$ for $15 \mathrm{~min}$ at $4^{\circ} \mathrm{C}$, serum was collected, aliquoted, and stored at $-80^{\circ} \mathrm{C}$. This study was approved by the Human Research Ethics Committee (HREC) from the Institute of Biomedical Sciences at the University of São Paulo, São Paulo, Brazil (protocol approval number 274.313). Sheep and rabbit erythrocytes were collected in Alsever's. All the procedures involving animals were in accordance with the ethical principles in animal research adopted by the Brazilian Society of Animal Science and the National Brazilian Legislation number 11.794/08. Protocols were approved by the Institutional Animal Care and Use Committee (protocol approval number 1111/13).

\subsection{Treatment of Normal Human Serum with B. lanceolatus} Venom. Normal human serum (NHS) was incubated with the same volume of $B$. lanceolatus venom in the appropriate buffer (i.e., for $\mathrm{CP}: \mathrm{VBS}^{2+}$; $\mathrm{AP}: \mathrm{APB}$; and $\mathrm{LP}: \mathrm{BVB}^{2+}$ ), at $37^{\circ} \mathrm{C}$ for $30 \mathrm{~min}$, to assess effects on the Complement system. Samples were tested for the remaining Complement activity or detection of the activation by-product. The role of metalloproteases in the venom was investigated by coincubation with 1,10-phenantroline (10 mM).

2.5. Haemolytic Complement Assays. Haemolytic activity was assessed using sensitized sheep erythrocytes $\left(\mathrm{E}_{\mathrm{S}}\right)$ for the $\mathrm{CP}$ [35], or rabbit erythrocytes $\left(\mathrm{E}_{\mathrm{R}}\right)$ for the AP [28]. $\mathrm{CH}_{50}$ and $\mathrm{AP}_{50}$ were calculated for each venom concentration. Venom concentrations able to inhibit $50 \%\left(\mathrm{IC}_{50}\right)$ of the activity of each pathway and their respective $95 \%$ confidence intervals (CI95\%) were determined from the curves of $\mathrm{CH}_{50}$ and $\mathrm{AP}_{50}$ plotted as a function of the logarithm of venom concentration by nonlinear regression using GraphPad Prism 6.0 software (GraphPad, La Jolla, CA, USA) [32, 35].

2.6. Action of B. lanceolatus Venom on Lectin Pathway. LP activity was assessed using mannan-coated microtiter plates and measurement of $\mathrm{C} 4$ deposition as previously described [28]. $\mathrm{LP}_{50}$ was calculated for each venom concentration. Venom concentrations able to inhibit $50 \%\left(\mathrm{IC}_{50}\right)$ of the activity of LP and its 95\% confidence interval (CI95\%) were determined from the values of $\mathrm{LP}_{50}$ for each venom concentration (see Section 2.5) by nonlinear regression using GraphPad Prism 6.0 software.

2.7. Detection of Anaphylatoxins and Terminal Complement Complex (TCC) in Venom-Treated Samples. C3a/C3adesArg, C4a/C4a-desArg, and C5a/C5a-desArg were measured using the Human Anaphylatoxin Cytometric Bead
Array (CBA) (BD Biosciences Pharmingen, San Diego, CA, USA), following the manufacturer's instructions. Cytometric analysis was performed using a FACSCanto-II (Becton Dickinson, San Diego, CA, USA), and the data were analysed with the Flow Cytometric Analysis Program (FCAP) Array 3.0 (Becton Dickinson, San Diego, CA, USA). Anaphylatoxin concentrations $(\mu \mathrm{g} / \mathrm{mL})$ were determined by linear regression from the standard curve. TCC (in its soluble form SC5b-9) was determined using the MicroVue ${ }^{\mathrm{TM}}$ SC5b-9 Plus EIA Kit (Quidel Corporation, San Diego, CA, USA), according to the manufacturer's instructions. TCC concentration $(\mu \mathrm{g} / \mathrm{mL})$ in the samples was calculated from a linear regression of the standard curve.

2.8. Cleavage of Purified Complement Components by B. lanceolatus Venom. To evaluate the direct cleavage of the Complement components by the B. lanceolatus venom, purified human Complement proteins, C3, C4, C5, and C1-INH ( $2 \mu \mathrm{g}$ from $0.2 \mathrm{mg} / \mathrm{mL}$ samples), were incubated with the same quantity of venom for $30 \mathrm{~min}$ at $37^{\circ} \mathrm{C}$. C1-INH was incubated with venom in the presence or absence of protease inhibitors, PMSF (20 mM), EDTA (20 mM), or 1,10-phenantroline $(20 \mathrm{mM})$. Samples were then submitted to SDS-PAGE (10\% separating gel) under reducing conditions and silverstained to detect cleavage $[36,37]$. In addition, cleavage of C1-INH was also revealed by Western blotting, using goat anti-human C1-INH antibodies $(1: 2000)$ and rabbit antigoat IgG labelled with alkaline phosphatase $(1: 7500)$. The reaction was developed by adding NBT/BCIP, following the instructions of the manufacturer.

2.9. Inhibitory Activity of C1-INH following Incubation with B. lanceolatus Venom. C1s-binding activity of C1-INH was assessed using the MicroVue ${ }^{\mathrm{TM}}$ C1-Inhibitor Plus EIA (Quidel Corporation, CA, USA), according to the manufacturer's procedure. Samples of purified human C1-INH were exposed to B. lanceolatus venom. As control, saline-treated C1-INH samples were used. Following the assay procedure, samples (diluted $1: 25$ ) were incubated with biotinylated C1s (venom concentration of $8 \mu \mathrm{g} / \mathrm{mL}$ ), and were incubated on avidine-coated microtiter plates. Horseradish peroxidase(HRP-) conjugated goat anti-human C1-INH was added to each test well and the reaction developed enabling the detection of C1-INH-C1s complexes deposited on the plates. After subtraction of the blank, the residual C1-INH-C1s-complexing activity of each sample was expressed as a percentage of the control sample activity.

2.10. Intracellular Calcium Flux Measurements. Functional C5a generation was assessed by measuring cytoplasmic calcium release from intracellular stores in leukocytes, of which neutrophils are the main population and the main responders, using the calcium indicator Fluo-4 AM. Leukocytes were separated from platelets and red blood cells by dextran sedimentation from heparinised human blood using standard procedures. Cells were resuspended in Dulbecco's modified Eagle's medium (DMEM), 10\% heat-inactivated foetal bovine serum (FBS), and loaded with the fluorescent calcium indicator Fluo- $4 \mathrm{AM}(1 \mu \mathrm{M})$ at $2 \mu \mathrm{g} / 10^{7}$ cells $/ \mathrm{mL}$, 


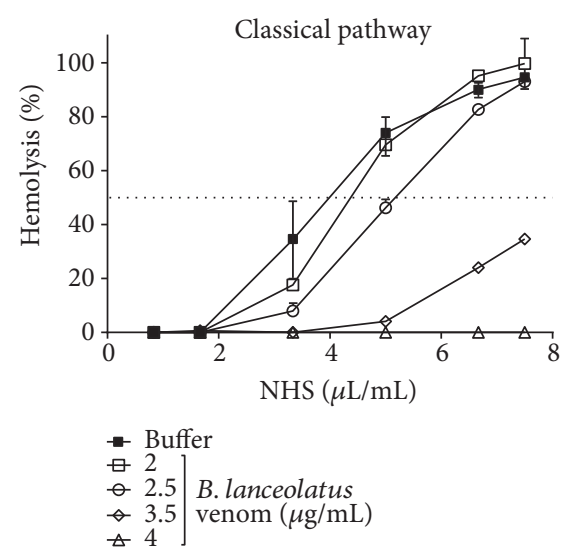

(a)

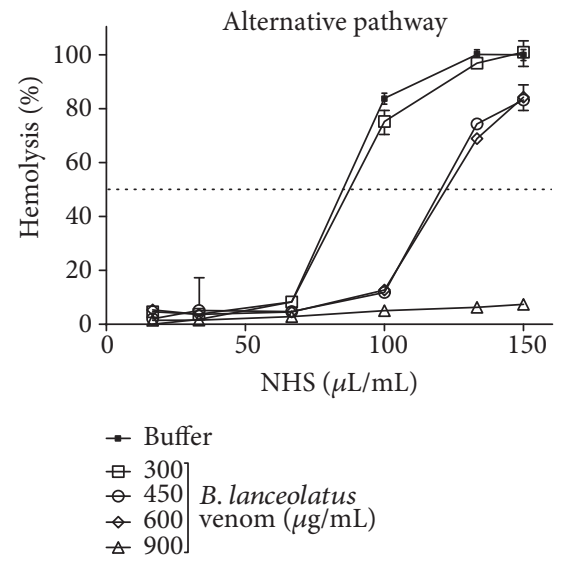

(b)

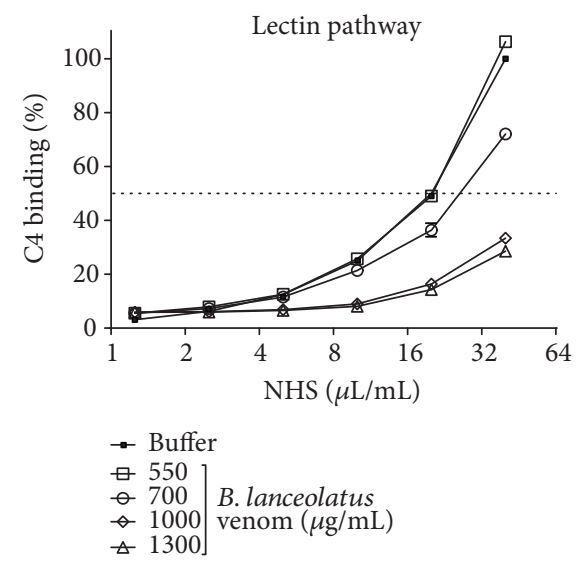

(c)

Figure 1: Activation of the three Complement pathways by B. lanceolatus venom. NHS (dilution $1: 80$ (a), $1: 4$ (b), and $1: 25$ (c)) was incubated with several concentrations of $B$. lanceolatus venom at $37^{\circ} \mathrm{C}$ for $1 \mathrm{~h}(\mathrm{CP})$ or $30 \mathrm{~min}$ (AP and LP), and diluted to test their residual Complement activity. NHS incubated only with buffer was used as control. (a) Sensitized sheep erythrocytes were used to assess the $\mathrm{CP}$ while (b) rabbit erythrocytes $\left(\mathrm{E}_{\mathrm{R}}\right)$ were used for the AP. (c) For the LP, residual binding of $\mathrm{C} 4$ on a mannan-coated plate was used. The results represent mean $\pm \mathrm{SD}$ of duplicates of a representative assay. Experiments were performed three times. The $\mathrm{CH}_{50}, \mathrm{AP}_{50}$, and $\mathrm{LP}_{50}$ were calculated by nonlinear regression from these curves. The $\mathrm{IC}_{50}$ of the venom for each pathway and respective CI95\% were calculated. The venom affected the classical pathway with an $\mathrm{IC}_{50}$ of $156.6 \mu \mathrm{g} / \mathrm{mL}$ of NHS (CI95\%: $147.3-166.6 \mu \mathrm{g} / \mathrm{mL}$ of NHS), the alternative pathway with an $\mathrm{IC}_{50}$ of $294.5 \mu \mathrm{g} / \mathrm{mL}$ of NHS (CI95\%: $273.2-317.4 \mu \mathrm{g} / \mathrm{mL}$ of NHS), and the LP pathway with an IC $\mathrm{In}_{50}$ of $396.3 \mu \mathrm{g} / \mathrm{mL}$ of NHS (CI95\%: $375.7-418.0 \mu \mathrm{g} / \mathrm{mL}$ of NHS).

at room temperature for $30 \mathrm{~min}$. Cells were washed with BSS and resuspended in Krebs buffer containing $0.1 \%$ BSA. Cells $\left(10^{6} /\right.$ well in $200 \mu \mathrm{L}$ Krebs buffer) were stimulated with venom-treated C5 $(10 \mu \mathrm{L} /$ well; final concentration of $9.5 \mu \mathrm{g} / \mathrm{mL})$, in a 96 -well plate and the fluorescence variations were measured every $3 \mathrm{sec}\left(\lambda_{\mathrm{ex}}=485 \mathrm{~nm}\right.$ and $\left.\lambda_{\mathrm{em}}=510 \mathrm{~nm}\right)$, using the fluorimeter FLUOstar Omega (BMG Labtech, Offenburg, Germany). As positive control, cells were exposed to purified C5a $(10 \mu \mathrm{L} /$ well; final concentration of $11.4 \mathrm{ng} / \mathrm{mL}$ ) and, as negative controls, cells were exposed to $\mathrm{C} 5$ or venom incubated with saline solution. For each well, the values of fluorescence were normalized by the initial fluorescence $\mathrm{F}_{0}$, the average fluorescence during $30 \mathrm{sec}$ before stimulation, and then plotted against time.

2.11. Cell Culture and Flow Cytometry. The endothelial cell line EA.hy926 was cultured in DMEM containing 10\% $(v / v)$ heat-inactivated FBS, and the antibiotics, penicillin, and streptomycin $(100 \mathrm{IU} / \mathrm{mL})$ at $37^{\circ} \mathrm{C}$ in humidified air with $5 \% \mathrm{CO}_{2}$. Cells were harvested using trypsin/EDTA and incubated at 106 cells $/ \mathrm{mL}$ with $100 \mu \mathrm{g} / \mathrm{mL}$ of B. lanceolatus venom, for $2 \mathrm{~h}$ at $37^{\circ} \mathrm{C}$ under constant agitation. Cells were centrifuged at $400 \times \mathrm{g}$ and resuspended in FACS buffer. Cells $\left(5 \times 10^{4}\right.$ cells/well $)$ were incubated for $1 \mathrm{~h}$ at $4^{\circ} \mathrm{C}$ with monoclonal antibodies anti-human MCP, DAF, or CD59 $(1 \mu \mathrm{g} / \mathrm{mL})$, followed by incubation with goat anti-mouse IgG-PE $(1: 100)$, for $1 \mathrm{~h}$ at $4^{\circ} \mathrm{C}$. Cells were analysed by flow cytometry (FACSCanto-II, Becton Dickinson, San Diego, CA, USA) using the software FACSDiva (Becton Dickinson, San Diego, CA, USA).

2.12. Statistics. Numerical data were expressed as mean \pm SD. Data were analysed statistically by Student's $t$-test, or by one way ANOVA and Bonferroni's multiple comparison test, using the software GraphPad Prism 6 (GraphPad Software, Inc., La Jolla, CA, USA). A $P$ value $<0.05$ was considered significant.

\section{Results}

3.1. B. lanceolatus Venom Affects All Three Complement Activation Pathways. Human serum (NHS) was incubated with $B$. lanceolatus venom and residual haemolytic activity was assessed. As shown in Figures 1(a) and 1(b), the venom dose-dependently reduced the lytic activity of CP and AP of NHS. The venom affected the classical pathway with an $\mathrm{IC}_{50}$ of $156.6 \mu \mathrm{g} / \mathrm{mL}$ (CI95\%: $147.3-166.6 \mu \mathrm{g} / \mathrm{mL}$ ) and the alternative pathway with an $\mathrm{IC}_{50}$ of $294.5 \mu \mathrm{g} / \mathrm{mL}$ (CI95\%: $273.2-317.4 \mu \mathrm{g} / \mathrm{mL}$ ) (Figures $1(\mathrm{a})$ and $1(\mathrm{~b})$ ). The venom also affected the $\mathrm{C} 4$ deposition in the LP assay, resulting in an $\mathrm{IC}_{50}$ of $396.3 \mu \mathrm{g} / \mathrm{mL}$ (CI95\%: 375.7-418.0 $\mu \mathrm{g} / \mathrm{mL}$ ) (Figure 1(c)).

\subsection{B. lanceolatus Venom Generates C4a and C5a and TCC in} NHS but Reduces C3a. To establish whether the observed reduction $\mathrm{C}$-activity resulted from inhibition or activation (resulting in consumption) of the Complement cascade by the venom, the presence of anaphylatoxins and terminal Complement complex (TCC) in venom-treated NHS samples was investigated. Figure 2 reveals that $B$. lanceolatus venom induces a significant production of $\mathrm{C} 4 \mathrm{a}, \mathrm{C} 5 \mathrm{a}$, and TCC, thus confirming direct activation of the Complement system by the venom. Surprisingly, the venom caused a significant decrease of $\mathrm{C} 3 \mathrm{a}$ in the serum, when compared with the control. These activities were inhibited with the addition of a metalloprotease inhibitor, 1,10-phenantroline, suggesting the participation of $B$. lanceolatus venom metalloproteases in Complement activation. 


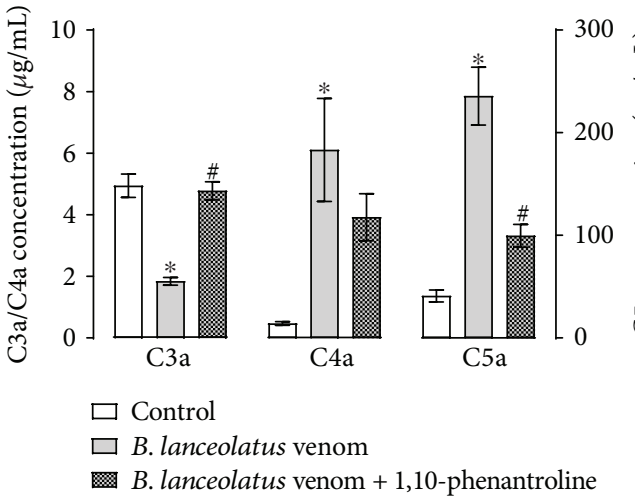

(a)

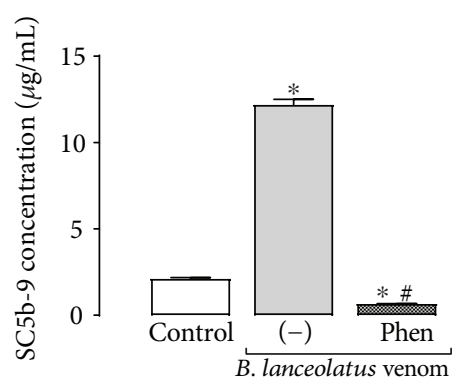

NHS treatment

FIGURE 2: Production of Complement activation products in NHS incubated with $B$. lanceolatus venom. NHS (diluted $1: 2$ in saline solution) was incubated with $B$. lanceolatus venom $(0.5 \mathrm{mg} / \mathrm{mL})$ for $30 \mathrm{~min}$ at $37^{\circ} \mathrm{C}$, in the presence or absence of 1,10 -phenantroline $(10 \mathrm{mM})$. As control, NHS was incubated with saline solution. (a) Samples were diluted 1:5000 and the concentrations of the anaphylatoxins C3a/C3adesArg, C4a/C4a-desArg, and C5a/C5a-desArg were determined using a cytometric bead array. (b) Samples were diluted 1:150, and the concentration of the SC5b-9 complex was measured by "MicroVue SC5b-9 Plus EIA Kit". The data represent two experiments, realized in duplicate. ${ }^{*} p<0.05$ compared to the saline-treated NHS controls. ${ }^{\#} p<0.05$ compared to venom-treated samples.

3.3. B. lanceolatus Venom Cleaves Purified C3, C4, and C5 and Generates Active C5a. Potential direct proteolytic action of the venom on the Complement components were investigated using purified $\mathrm{C} 3, \mathrm{C} 4$, and $\mathrm{C} 5$ and incubations with $B$. lanceolatus venom, in the presence or absence of proteases inhibitors. SDS-PAGE (Figures 3 and 4) shows that the venom reduced the intensity of staining of the $\alpha$-chains of C3, C4, and C5 while generating fragments of slightly lower molecular mass, a pattern similar to what is usually observed when these molecules are activated via any of the Complement cascade. $\beta$ - and $\gamma$-chains were not significantly affected.

To further investigate if the C5a fragment produced by the direct action of venom was functional, we measured its ability to activate leukocytes, by means of monitoring the calcium influx induced by C5a in these cells. Neutrophils constitute the major cell type in the leukocyte preparations and are the main and strongest responders to C5a in leukocyte preparations. Leukocytes, preloaded with the calcium sensor Fluo-4 AM, were exposed to venom-treated C5 samples. Figure 3(d) demonstrates that venom-treated C5, similar to purified C5a, is able to induce a calcium influx in leukocytes, demonstrating that functionally active C5a was generated. Venom on its own or purified C5 on its own, did not induce a change in intracellular calcium.

\subsection{B. lanceolatus Venom Cleaves and Partially Inactivates} C1-INH. We previously showed that venoms from a range of Bothrops snakes caused the cleavage of C1-INH, the soluble regulator of the classical and lectin pathways. We show here that $B$. lanceolatus venom also has that ability (Figure 4). Both silver-staining (Figure 4(a)) and Western blotting (Figure 4(b)) showed that the single-chain C1-INH (reported to have a $\mathrm{Mr}$ of $105 \mathrm{kDa}$ [38]) was reduced in $\mathrm{Mr}$ by the venom action (with a reduction in size to approximately $98 \mathrm{kDa}$ ). This activity was totally inhibited by the metalloprotease inhibitors, EDTA and 1,10-phenantroline, whereas the inhibition displayed by the serine protease inhibitor, PMSF, was partial (Figures 4(a) and 4(b)). Using a functional ELISA assay testing the binding of $\mathrm{C} 1 \mathrm{~s}$, we observed that the venom-generated C1-INH fragments had a reduced binding activity to C1s (Figure 4(c)), as compared to the nonvenom-treated purified component, indicating that it was inactivated by the venom.

3.5. B. lanceolatus Venom Does Not Reduce Expression of Membrane-Bound C-Regulators. The Complement system also includes regulatory proteins present on the cell membranes, and reduction in expression on endothelial cells would make cells more susceptible to C-induced activation. Using the endothelial cell line EA.hy926, we investigated the effects of $B$. lanceolatus venom on the expression of membrane-bound C-regulators DAF, MCP, and CD59. The venom significantly increased the expression of MCP and CD59 and did not affect DAF expression (Figure 5).

\section{Discussion}

B. lanceolatus, commonly called the Martinique lancehead and Martinican pit viper, is the only endemic snake on Martinique [1,2]. Clinical presentations of envenomations by $B$. lanceolatus are characterized by systemic thrombotic syndrome and important local inflammation, involving oedema and pain, but limited haemorrhage.

The Complement system is an important contributor to and amplificator of inflammation if activated in excess or inappropriately controlled. Anaphylatoxins generated as a consequence of $\mathrm{C}$ activation are major contributors to the inflammation. The Complement system can also contribute to thrombosis by activating endothelial cells and contributing to platelet activation, and both anaphylatoxins and the TCC are contributors [27]. In this study, we analysed the action of $B$. lanceolatus venom on the Complement system activation pathways, components, regulators, and receptors. We 


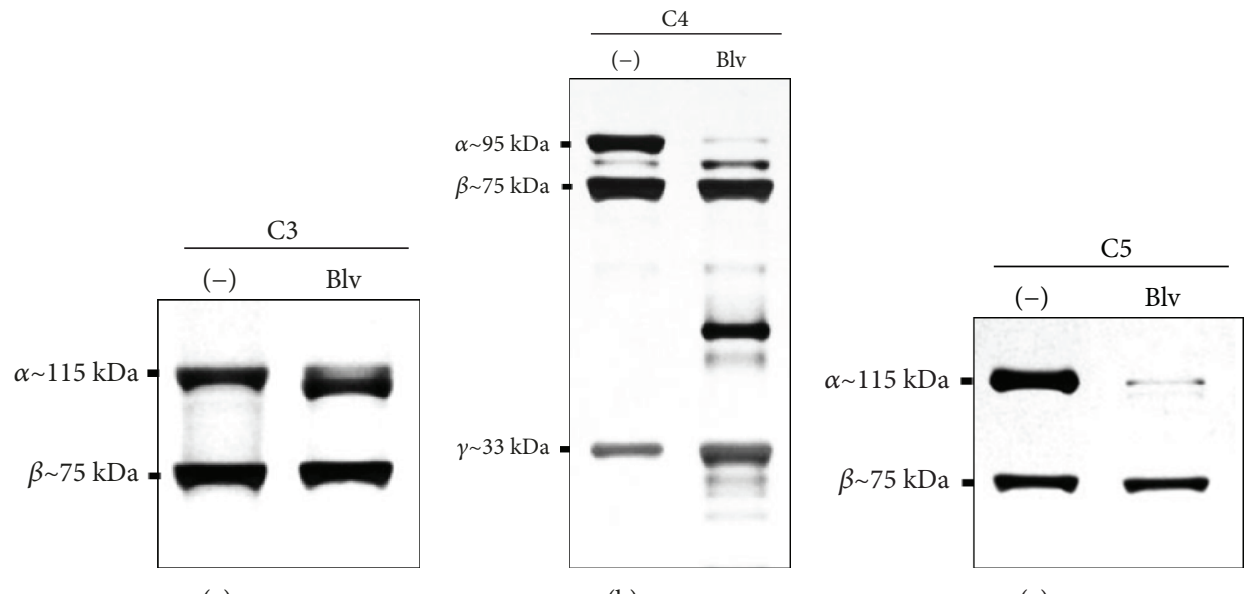

(a)

(b)

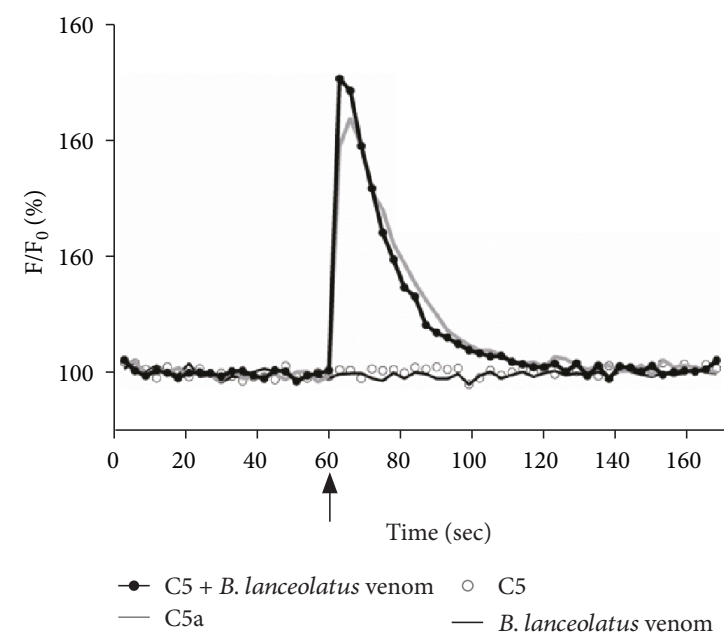

(d)

Figure 3: Cleavage of purified C3, C4, and C5 by B. lanceolatus venom. Samples ( $2 \mu \mathrm{g}$ ) of purified Complement components C3 (a), C4 (b), and C5 (c) were incubated in PBS with B. lanceolatus venom $(2 \mu \mathrm{g})$ for $30 \mathrm{~min}$ at $37^{\circ} \mathrm{C}$. The cleavage was visualized by electrophoretic separation ( $10 \%$ acrylamide SDS-PAGE) under reducing conditions, followed by silver staining. (d) The functional activity of the venom-treated C5 fragments was assessed via measuring calcium influx in Fluo-4-AM-labelled leukocytes $\left(5 \times 10^{6}\right.$ cells $\left./ \mathrm{mL}\right)$. Purified C5a $(2.4 \mathrm{ng} / \mathrm{mL})$ and samples of C5 or venom incubated with saline were used as positive and negative controls, respectively. Cells were allowed to equilibrate for $60 \mathrm{sec}$ before stimulation (arrow).

show here that the venom can activate all three Complement pathways (Figure 1). Activation of the AP may be simply a consequence of activation of the LP and CP, which often also results in activation of the $\mathrm{AP}$, which then acts as an amplification loop. Recently, we have demonstrated the presence of glycosylated proteins in this venom [10], which potentially are involved the lectin pathway activation; however, this remains to be investigated.

Complement activation by $B$. lanceolatus venom was also demonstrated by the detection of $\mathrm{C}$-activation products, such as the anaphylatoxins $\mathrm{C} 4 \mathrm{a}$ and $\mathrm{C} 5 \mathrm{a}$ and TCC (Figure 2). However, a decrease rather than an increase in the concentration of $\mathrm{C} 3 \mathrm{a}$ was detected in venom-treated NHS. We have previously shown that out of venoms from 19 different Bothrops species, 18 induced the generation of C3a in serum, but similar to B. lanceolatus, the B. brazili venom also induced a reduction in C3a [28]. These results may be due to the presence of venom peptidases able to further hydrolyse C3a. C3a is a potent proinflammatory signal for several cell types, such as macrophages/monocytes, peripheral nonadherent PBMCs, and mast cells [39]. In contrast to C5a, C3a does not directly activate neutrophils and can prevent their mobilization from bone marrow to the blood stream, which constitutes an anti-inflammatory action in the early phase of inflammation [39-41]. Thus, the reduction of $\mathrm{C} 3 \mathrm{a}$ and the increase of $\mathrm{C} 5 \mathrm{a}$ in $\mathrm{B}$. lanceolatus venom may contribute to its potent proinflammatory action. However, further kinetics studies analysing C3a and C5a generation and degradation, are necessary to define the possible consequences of these results in the envenomation process.

Analysis of the contributions of metalloproteases, common components of Bothrops venoms, showed that the metalloprotease inhibitor 1,10-phenanthroline partially or completely prevented the effects of the venom on the generation of anaphylatoxins and TCC in whole serum 


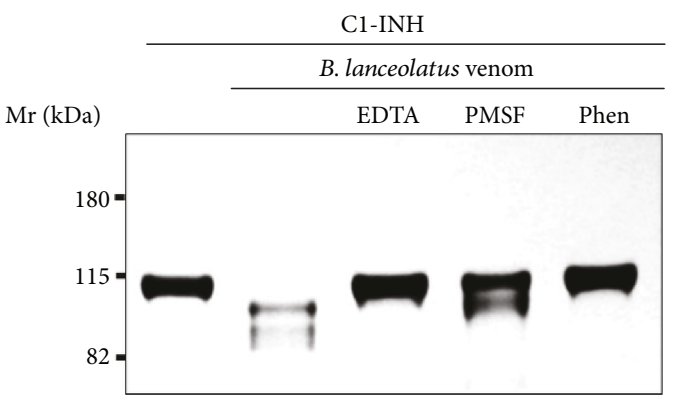

(a)

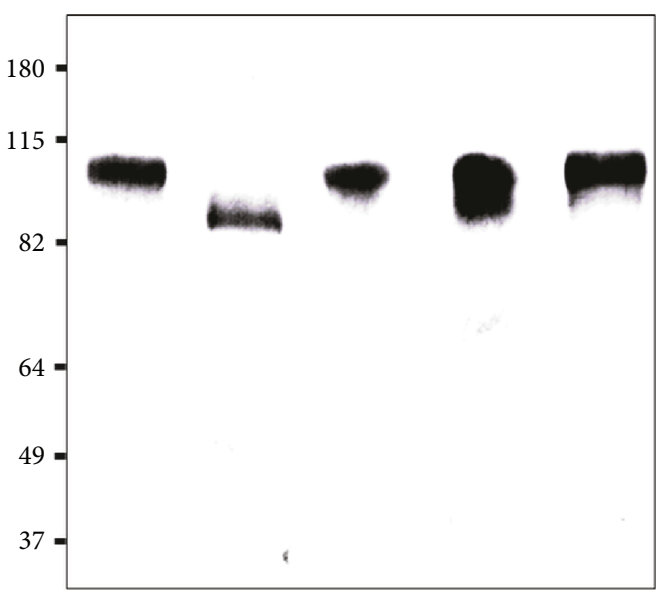

(b)

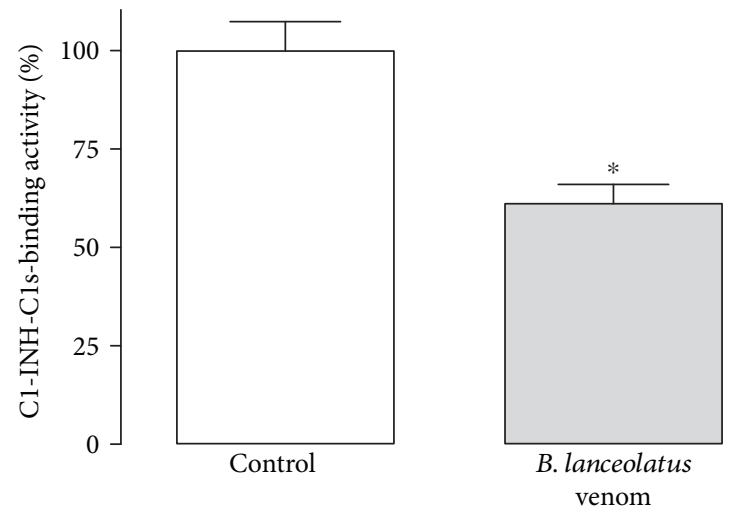

Treatments

(c)

FIgURE 4: Cleavage of purified Complement regulator C1-INH by B. lanceolatus venom and its residual C1s-complexing activity. C1-INH $(2 \mu \mathrm{g})$ samples were incubated with B. lanceolatus venom $(2 \mu \mathrm{g})$ for $30 \mathrm{~min}$ at $37^{\circ} \mathrm{C}$ and the cleavage was visualized by SDS-PAGE electrophoresis, followed by silver staining (a), or by Western blot using anti-C1-INH antibodies (b). The residual C1s-complexing activity of the C1-INH fragments was assessed by functional ELISA (c). The results represent the mean of two independent experiments, carried out in triplicates. Data are represented as mean \pm SD. ${ }^{*} p<0.05$ between two samples.

(Figure 2), suggesting an important role for metalloproteases in the activation of the Complement system. The role of serine proteases in this process cannot be investigated as the enzymes in the Complement system themselves are serine proteases.

Considering that Bothrops venoms contain a large amount of proteases, we analysed the ability of B. lanceolatus venom to directly cleave the sources of anaphylatoxins, such as C3, C4, and C5. Data presented here show that venom components can hydrolyse the $\alpha$-chain of the three Complement proteins (Figure 3 ). These fragments could participate or be the origin of the potent activation of the three pathways by the venom; however, their functional activity remains to be tested. Purification of venom components would be required to investigate the identity of the components responsible for Complement activation and enzymatic cleavage of purified components.

We also show here that the C5a fragment, generated through the degradation of purified C5 by B. lanceolatus venom, is functionally active, demonstrating that venom proteases directly cleave C5 into functional C5a (Figure 3(d)). The cleavage of C5 after envenomation, due to the generation of a C5-convertase, as a consequence of the activation of the three Complement pathways, is likely an important mechanism in the generation of C5a (Figures 1 and 2). In addition, direct activation of C5a is a possibility, and thrombin-like enzymes have already been reported in Bothrops sp. venoms [42-44] and may be responsible for the direct generation of $\mathrm{C} 5 \mathrm{a}$, since human thrombin can cleave C5 into functional C5a. As activated human coagulation proteins (e.g., thrombin, plasmin, FX, and FXIa) are known to activate C5 $[42,45]$, further C5a could also be generated. Considering that both $\mathrm{C} 5 \mathrm{a}$ [46-48] and TCC [49-51] can display several prothrombotic effects, how these two C-activation products contribute to the prothrombotic pathology observed in $B$. lanceolatus envenomation requires further investigation.

The C1-inhibitor, C1-INH, is the only known serine protease plasma inhibitor. It regulates not only the Complement cascade (inhibitor of $\mathrm{C} 1 \mathrm{r}, \mathrm{C} 1 \mathrm{~s}$, and MASPs) but is also an 


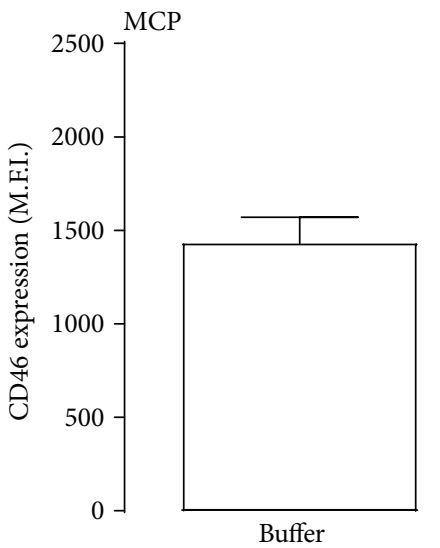

Treatments

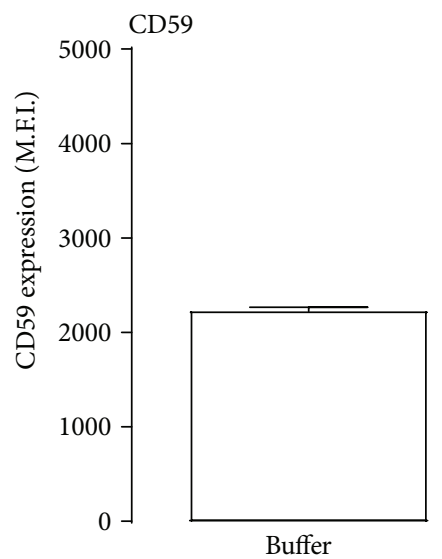

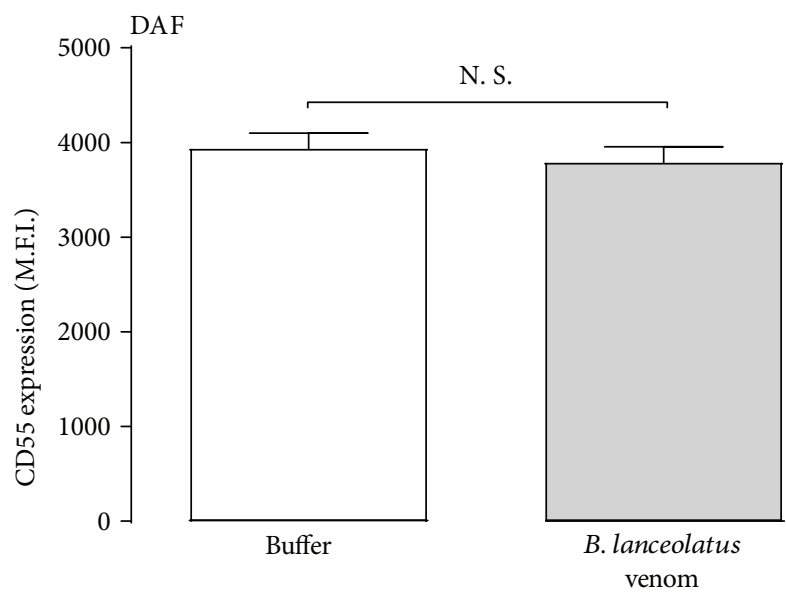

Treatments

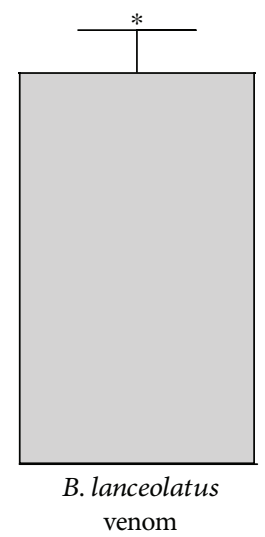

Treatments

Figure 5: Effect of $B$. lanceolatus venom exposure on C-regulator expression on endothelial cells. EA.hy926 cells (10 6 cells $/ \mathrm{mL})$ were incubated with B. lanceolatus venom $(100 \mu \mathrm{g} / \mathrm{mL})$ for $2 \mathrm{~h}$. After incubation with DAF-, MCP-, and CD59-specific antibodies, the fluorescence was assessed by flow cytometry. The results are representative of two experiments, carried out in triplicates. Data are represented as mean \pm SD. ${ }^{*} p<0.05$ compared to the buffer-treated controls. ${ }^{*} p<0.05$ between two samples.

important regulator of the coagulation cascade activation and inhibits several fibrinolytic proteins (kallikrein, FXIIa, FXIa, and plasmin) [52]. It inhibits the Complement serine protease $\mathrm{C} 1 \mathrm{~s}$ by acting as a pseudosubstrate: $\mathrm{C} 1-\mathrm{INH}$ is cleaved at the peptide-bound R444-T445 and forms a stable complex with C1s via its residues Q452, Q453, and F455 [53]. A deficiency of C1-INH can result in autoactivation of these pathways [54]. Our results reveal that B. lanceolatus venom also cleaves purified C1-INH, mainly by metalloprotease action, which may explain the activation of the $\mathrm{C}$-cascades. In conditions of complete $\mathrm{C} 1$-INH conversion by $B$. lanceolatus venom, the C1s-inhibitory potential loss was about $40 \%$, similar to the value observed with $B$. pirajai metalloprotease, C-SVMP, under comparable conditions [32]. This loss of function could result from C1s-binding site impairment by the venom. It could be related to the activation of classical and lectin pathways by $B$. lanceolatus venom. Furthermore, $\mathrm{C} 1-\mathrm{INH}$ is also an important regulator of several proteins involved in the coagulation cascade and dysfunction or deficiency of $\mathrm{C} 1-\mathrm{INH}$ can lead to excess generation of bradykinin, a potent vasodilator and important contributor to inflammation, and is associated with hereditary angioedema (HAE) [52]. This may be the major mechanism of how $B$. lanceolatus venom induces inflammation.

As Complement activation on endothelial cells can lead to a more prothrombotic phenotype of these cells [55], endothelial cells express Complement inhibitors on their membrane, such as membrane cofactor protein (MCP/CD46), decay-accelerating factor (DAF/CD55), and CD59 [56]. A deficiency of MCP has been associated with atypical human uraemic syndrome (aHUS) which is characterized by thrombotic microangiopathies [57], while a deficiency of DAF/ CD59 is associated with paroxysmal nocturnal haemoglobinuria $(\mathrm{PNH})$, which also is associated with thrombosis [58]. 
Furthermore, we previously reported the cleavage of MCP induced by Loxosceles spider venom [59] and this might contribute to the systemic thrombotic events associated with envenomation. In our study, the B. lanceolatus venom did not reduce expression of any of these regulators but, significantly, increased the detection of MCP and CD59 (Figure 5). Thus, increased thrombosis after B. lanceolatus envenomation is unlikely due to inefficient $C$ regulation on the endothelial cells, but endothelial activation in response to excess C5a or TCC generation, as a consequence of the effect of the venom on the Complement system, may contribute. Bothrops species venoms activate the Complement cascade by several pathways and complex mechanisms [28]. In the case of $B$. asper and B. pirajai venoms, class I metalloproteases are involved [30,32]. Since structural similarities exist between Bothrops toxins, B. lanceolatus PI-SVMPs may be involved in B. lanceolatus Complement activation, but this remains to be investigated.

In conclusion, here we show that, like its continental counterparts, B. lanceolatus venom is a potent trigger of the Complement cascade in vitro. Thus, further in vivo studies may support the idea that therapeutic management of systemic B. lanceolatus envenomation could include the use of Complement inhibitors as adjunct therapy.

\section{Conflicts of Interest}

The authors declare that they have no conflict of interest regarding the publication of this article.

\section{Acknowledgments}

This study was supported by Instituto Nacional de Ciência e Tecnologia em Toxinas (INCTTox) and Prevor. Denise V. Tambourgi is a CNPq fellow (301358/2017-6).

\section{References}

[1] J. M. Gutiérrez, "Clinical toxicology of snakebite in Central America," in Handbook of Clinical Toxicology of Animal Venoms and Poisons, J. White and M. Jurg, Eds., pp. 645665, CRC Press, Boca Raton, FL, USA, 1995.

[2] D. Resiere, B. Mégarbane, R. Valentino, H. Mehdaoui, and L. Thomas, "Bothrops lanceolatus bites: guidelines for severity assessment and emergent management," Toxins, vol. 2, no. 1, pp. 163-173, 2010.

[3] F. O. S. França and C. M. S. Málaque, “Acidente botrópico," in Animais peçonhentos no Brasil: Biologia, J. L. C. Cardoso, F. O. S. França, F. H. Wen, C. M. S. Málaque, and V. Haddad Jr., Eds., pp. 72-86, Clínica e Terapêutica dos Acidentes Sarvier, São Paulo, Brazil, 2003.

[4] R. Otero, J. Gutiérrez, María Beatriz Mesa et al., "Complications of Bothrops, Porthidium, and Bothriechis snakebites in Colombia. A clinical and epidemiological study of 39 cases attended in a university hospital," Toxicon, vol. 40, no. 8, pp. 1107-1114, 2002.

[5] S. Malbranque, M. D. Piercecchi-Marti, L. Thomas et al., "Fatal diffuse thrombotic microangiopathy after a bite by the "Ferde-Lance" pit viper (Bothrops lanceolatus) of Martinique,"
The American Journal of Tropical Medicine and Hygiene, vol. 78, no. 6, pp. 856-861, 2008.

[6] L. Thomas, N. Chausson, J. Uzan et al., "Thrombotic stroke following snake bites by the "Fer-de-Lance" Bothrops lanceolatus in Martinique despite antivenom treatment: a report of three recent cases," Toxicon, vol. 48, no. 1, pp. 23-28, 2006.

[7] T. C. Antunes, K. M. Yamashita, K. C. Barbaro, M. Saiki, and M. L. Santoro, "Comparative analysis of newborn and adult Bothrops jararaca snake venoms," Toxicon, vol. 56, no. 8, pp. 1443-1458, 2010.

[8] F. Aragon, R. Bolanos, and O. Vargas, "Carbohydrates of the venoms of Bothrops asper of Costa Rica. Quantitative study," Revista de biologia tropical, vol. 25, no. 2, pp. 171-178, 1977.

[9] J. J. Calvete, L. Sanz, A. Pérez et al., "Snake population venomics and antivenomics of Bothrops atrox: paedomorphism along its transamazonian dispersal and implications of geographic venom variability on snakebite management," Journal of Proteomics, vol. 74, no. 4, pp. 510-527, 2011.

[10] M. Delafontaine, I. M. Villas-Boas, L. Mathieu, P. Josset, J. Blomet, and D. V. Tambourgi, "Enzymatic and proinflammatory activities of Bothrops lanceolatus venom: relevance for envenomation," Toxins, vol. 9, no. 8, 2017.

[11] G. P. Queiroz, L. A. Pessoa, F. C. V. Portaro, M. d. F. D. Furtado, and D. V. Tambourgi, "Interspecific variation in venom composition and toxicity of Brazilian snakes from Bothrops genus," Toxicon, vol. 52, no. 8, pp. 842-851, 2008.

[12] R. M. S. Terra, A. F. M. Pinto, J. A. Guimarães, and J. W. Fox, "Proteomic profiling of snake venom metalloproteinases (SVMPs): insights into venom induced pathology," Toxicon, vol. 54, no. 6, pp. 836-844, 2009.

[13] J. M. Gutiérrez, L. Sanz, J. Escolano et al., "Snake venomics of the lesser Antillean pit vipers Bothrops caribbaeus and Bothrops lanceolatus: correlation with toxicological activities and immunoreactivity of a heterologous antivenom," Journal of Proteome Research, vol. 7, no. 10, pp. 4396-4408, 2008.

[14] J. M. Gutiérrez, A. Rucavado, T. Escalante, and C. Díaz, "Hemorrhage induced by snake venom metalloproteinases: biochemical and biophysical mechanisms involved in microvessel damage," Toxicon, vol. 45, no. 8, pp. 997-1011, 2005.

[15] S. M. T. Serrano and R. C. Maroun, "Snake venom serine proteinases: sequence homology vs. substrate specificity, a paradox to be solved," Toxicon, vol. 45, no. 8, pp. 1115-1132, 2005.

[16] G. Arbore, C. Kemper, and M. Kolev, "Intracellular complement-the complosome-in immune cell regulation," Molecular Immunology, vol. 89, pp. 2-9, 2017.

[17] M. C. Carroll, "Complement and humoral immunity," Vaccine, vol. 26, Supplement 8, pp. I28-I33, 2008.

[18] N. Danilova, "The evolution of immune mechanisms," Journal of Experimental Zoology Part B: Molecular and Developmental Evolution, vol. 306B, no. 6, pp. 496-520, 2006.

[19] C. H. Nielsen, E. M. Fischer, and R. G. Q. Leslie, “The role of Complement in the acquired immune response," Immunology, vol. 100 , no. 1 , pp. 4-12, 2000.

[20] M. K. Pangburn, V. P. Ferreira, and C. Cortes, "Discrimination between host and pathogens by the Complement system," Vaccine, vol. 26, Supplement 8, pp. I15-I21, 2008.

[21] A. P. Sjoberg, L. A. Trouw, and A. M. Blom, "Complement activation and inhibition: a delicate balance," Trends in Immunology, vol. 30, no. 2, pp. 83-90, 2009.

[22] T. Monsinjon, P. Gasque, P. Chan, A. Ischenko, J. J. Brady, and M. Fontaine, "Regulation by Complement $\mathrm{C} 3 \mathrm{a}$ and $\mathrm{C} 5 \mathrm{a}$ 
anaphylatoxins of cytokine production in human umbilical vein endothelial cells," The FASEB Journal, vol. 17, no. 9, pp. 1003-1014, 2003.

[23] B. Bowen, J. J. Hawk, S. Sibunka, S. Hovick, and J. M. Weiler, "A review of the reported defects in the human $\mathrm{C} 1$ esterase inhibitor gene producing hereditary angioedema including four new mutations," Clinical Immunology, vol. 98, no. 2, pp. 157-163, 2001.

[24] J. Kohl, "Self, non-self, and danger: a complementary view," Advances in Experimental Medicine and Biology, vol. 586, pp. 71-94, 2006.

[25] T. Miwa and W. C. Song, "Membrane Complement regulatory proteins: insight from animal studies and relevance to human diseases," International Immunopharmacology, vol. 1, no. 3, pp. 445-459, 2001.

[26] M. Noris and G. Remuzzi, "Overview of Complement activation and regulation," Seminars in Nephrology, vol. 33, no. 6, pp. 479-492, 2013.

[27] K. N. Ekdahl, Y. Teramura, O. A. Hamad et al., "Dangerous liaisons: complement, coagulation, and kallikrein/kinin cross-talk act as a linchpin in the events leading to thromboinflammation," Immunological Reviews, vol. 274, no. 1, pp. 245-269, 2016.

[28] G. Pidde-Queiroz, M. d. F. Furtado, C. F. Filgueiras et al., "Human Complement activation and anaphylatoxins generation induced by snake venom toxins from Bothrops genus," Molecular Immunology, vol. 47, no. 16, pp. 2537-2544, 2010.

[29] D. V. Tambourgi and C. W. van den Berg, "Animal venoms/ toxins and the Complement system," Molecular Immunology, vol. 61, no. 2, pp. 153-162, 2014.

[30] S. H. P. Farsky, L. R. C. Gonçalves, J. M. Gutiérrez et al., "Bothrops asper snake venom and its metalloproteinase BaP-1 activate the complement system. Role in leucocyte recruitment," Mediators of Inflammation, vol. 9, no. 5, pp. 213-221, 2000.

[31] D. L. Menaldo, C. P. Bernardes, J. C. Pereira et al., "Effects of two serine proteases from Bothrops pirajai snake venom on the Complement system and the inflammatory response," International Immunopharmacology, vol. 15, no. 4, pp. 764771, 2013.

[32] G. Pidde-Queiroz, F. C. Magnoli, F. C. V. Portaro et al., "P-I snake venom metalloproteinase is able to activate the Complement system by direct cleavage of central components of the cascade," PLoS Neglected Tropical Diseases, vol. 7, no. 10, article e2519, 2013.

[33] A. L. de Araújo, A. Kamiguti, and C. Bon, "Coagulant and anticoagulant activities of Bothrops lanceolatus (Fer de Lance) venom," Toxicon, vol. 39, no. 2-3, pp. 371-375, 2001.

[34] N. Kawasaki, T. Kawasaki, and I. Yamashina, "Isolation and characterization of a mannan-binding protein from human serum," Journal of Biochemistry, vol. 94, no. 3, pp. 937947, 1983.

[35] I. M. Villas Boas, G. Pidde-Queiroz, F. C. Magnoli, R. M. Goncalves-de-Andrade, C. W. van den Berg, and D. V. Tambourgi, "A serine protease isolated from the bristles of the Amazonic caterpillar, Premolis semirufa, is a potent Complement system activator," PLoS One, vol. 10, no. 3, article e0118615, 2015.

[36] U. K. Laemmli, "Cleavage of structural proteins during the assembly of the head of bacteriophage T4," Nature, vol. 227, no. 5259 , pp. $680-685,1970$.
[37] J. H. Morrissey, "Silver stain for proteins in polyacrylamide gels: a modified procedure with enhanced uniform sensitivity," Analytical Biochemistry, vol. 117, no. 2, pp. 307-310, 1981.

[38] R. A. Harrison, "Human C.lovin.1 inhibitor: improved isolation and preliminary structural characterization," Biochemistry, vol. 22, no. 21, pp. 5001-5007, 1983.

[39] L. G. Coulthard and T. M. Woodruff, "Is the Complement activation product $\mathrm{C} 3 \mathrm{a}$ a proinflammatory molecule? Reevaluating the evidence and the myth," The Journal of Immunology, vol. 194, no. 8, pp. 3542-3548, 2015.

[40] P. J. Daffern, P. H. Pfeifer, J. A. Ember, and T. E. Hugli, "C3a is a chemotaxin for human eosinophils but not for neutrophils. I. C3a stimulation of neutrophils is secondary to eosinophil activation," The Journal of Experimental Medicine, vol. 181, no. 6, pp. 2119-2127, 1995.

[41] M. C. L. Wu, F. H. Brennan, J. P. L. Lynch et al., “The receptor for Complement component $\mathrm{C} 3 \mathrm{a}$ mediates protection from intestinal ischemia-reperfusion injuries by inhibiting neutrophil mobilization," Proceedings of the National Academy of Sciences of the United States of America, vol. 110, no. 23, pp. 9439-9444, 2013.

[42] U. Amara, M. A. Flierl, D. Rittirsch et al., "Molecular intercommunication between the Complement and coagulation systems," The Journal of Immunology, vol. 185, no. 9, pp. 5628-5636, 2010.

[43] M. J. Krisinger, V. Goebeler, Z. Lu et al., "Thrombin generates previously unidentified $\mathrm{C} 5$ products that support the terminal Complement activation pathway," Blood, vol. 120, no. 8, pp. 1717-1725, 2012.

[44] A. Lôbo de Araújo, J. L. Donato, and C. Bon, "Purification from Bothrops lanceolatus (fer de lance) venom of a fibrino(geno)lytic enzyme with esterolytic activity," Toxicon, vol. 36, no. 5, pp. 745-758, 1998.

[45] U. Amara, D. Rittirsch, M. Flierl et al., "Interaction between the coagulation and Complement system," Advances in Experimental Medicine and Biology, vol. 632, pp. 71-79, 2008.

[46] J. L. Platt, A. P. Dalmasso, B. J. Lindman, N. S. Ihrcke, and F. H. Bach, "The role of C5a and antibody in the release of heparan sulfate from endothelial cells," European Journal of Immunology, vol. 21, no. 11, pp. 2887-2890, 1991.

[47] K. Ritis, M. Doumas, D. Mastellos et al., “A novel C5a receptor-tissue factor cross-talk in neutrophils links innate immunity to coagulation pathways," The Journal of Immunology, vol. 177, no. 7, pp. 4794-4802, 2006.

[48] J. Wojta, K. Huber, and P. Valent, "New aspects in thrombotic research: complement induced switch in mast cells from a profibrinolytic to a prothrombotic phenotype," Pathophysiology of Haemostasis and Thrombosis, vol. 33, no. 5-6, pp. 438-441, 2003.

[49] F. Bossi, F. Fischetti, V. Pellis et al., "Platelet-activating factor and kinin-dependent vascular leakage as a novel functional activity of the soluble terminal Complement complex," The Journal of Immunology, vol. 173, no. 11, pp. 6921-6927, 2004.

[50] K. K. Hamilton, R. Hattori, C. T. Esmon, and P. J. Sims, "Complement proteins C5b-9 induce vesiculation of the endothelial plasma membrane and expose catalytic surface for assembly of the prothrombinase enzyme complex," The Journal of Biological Chemistry, vol. 265, no. 7, pp. 3809-3814, 1990.

[51] F. Tedesco, M. Pausa, E. Nardon, M. Introna, A. Mantovani, and A. Dobrina, "The cytolytically inactive terminal Complement complex activates endothelial cells to express adhesion 
molecules and tissue factor procoagulant activity," The Journal of Experimental Medicine, vol. 185, no. 9, pp. 1619-1628, 1997.

[52] A. P. Kaplan and K. Joseph, "Complement, kinins, and hereditary angioedema: mechanisms of plasma instability when $\mathrm{C} 1$ inhibitor is absent," Clinical Reviews in Allergy and Immunology, vol. 51, no. 2, pp. 207-215, 2016.

[53] S. He, R. B. Sim, and K. Whaley, "A secondary C1s interaction site on C1-inhibitor is essential for formation of a stable enzyme-inhibitor complex," FEBS Letters, vol. 405, no. 1, pp. 42-46, 1997.

[54] A. E. Davis III, F. Lu, and P. Mejia, "C1 inhibitor, a multi-functional serine protease inhibitor," Thrombosis and Haemostasis, vol. 104, no. 5, pp. 886-893, 2010.

[55] D. Karpman and R. Tati, "Complement activation in thrombotic microangiopathy," Hämostaseologie, vol. 33, no. 2, pp. 96-104, 2013.

[56] S. Tsuji, K. Kaji, and S. Nagasawa, "Decay-accelerating factor on human umbilical vein endothelial cells. Its histamineinduced expression and spontaneous rapid shedding from the cell surface," The Journal of Immunology, vol. 152, no. 3, pp. 1404-1410, 1994.

[57] M. K. Liszewski and J. P. Atkinson, "Complement regulator CD46: genetic variants and disease associations," Human Genomics, vol. 9, no. 1, p. 7, 2015.

[58] A. Hill, A. E. DeZern, T. Kinoshita, and R. A. Brodsky, "Paroxysmal nocturnal haemoglobinuria," Nature Reviews Disease Primers, vol. 3, article 17028, 2017.

[59] C. W. van den Berg, R. M. G. De Andrade, F. C. Magnoli, K. J. Marchbank, and D. V. Tambourgi, "Loxosceles spider venom induces metalloproteinase mediated cleavage of MCP/CD46 and MHCI and induces protection against C-mediated lysis," Immunology, vol. 107, no. 1, pp. 102-110, 2002. 


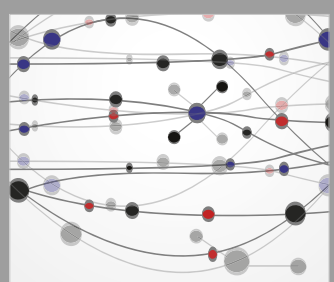

The Scientific World Journal
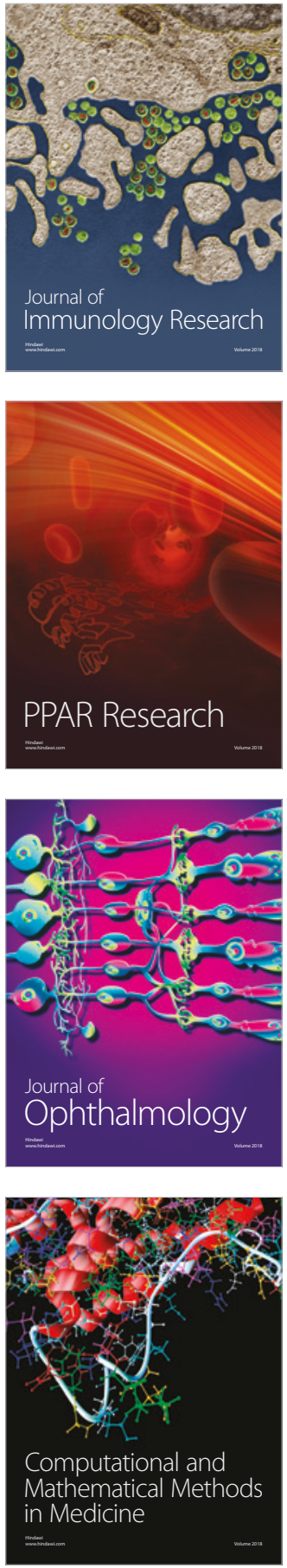

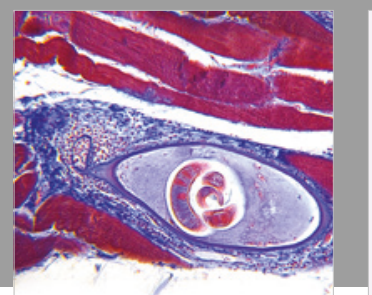

Gastroenterology Research and Practice

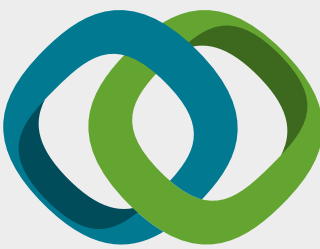

\section{Hindawi}

Submit your manuscripts at

www.hindawi.com
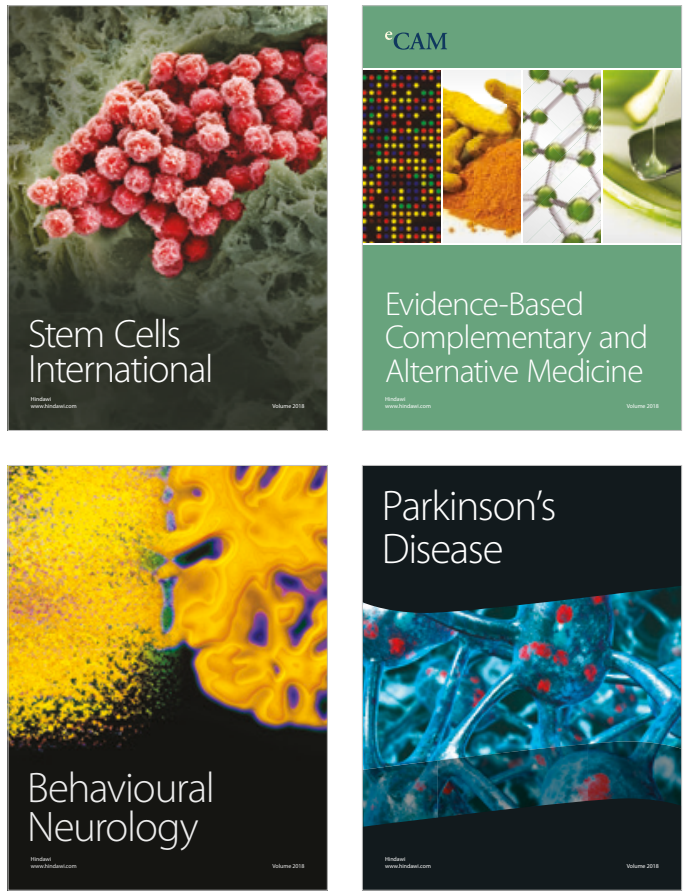

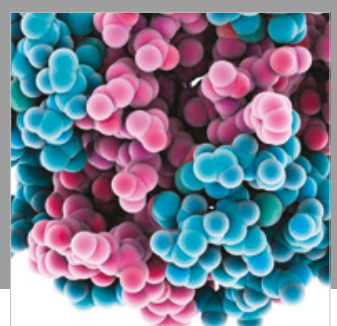

ournal of

Diabetes Research

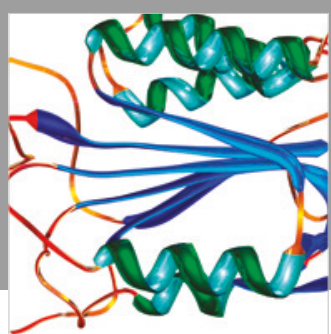

Disease Markers
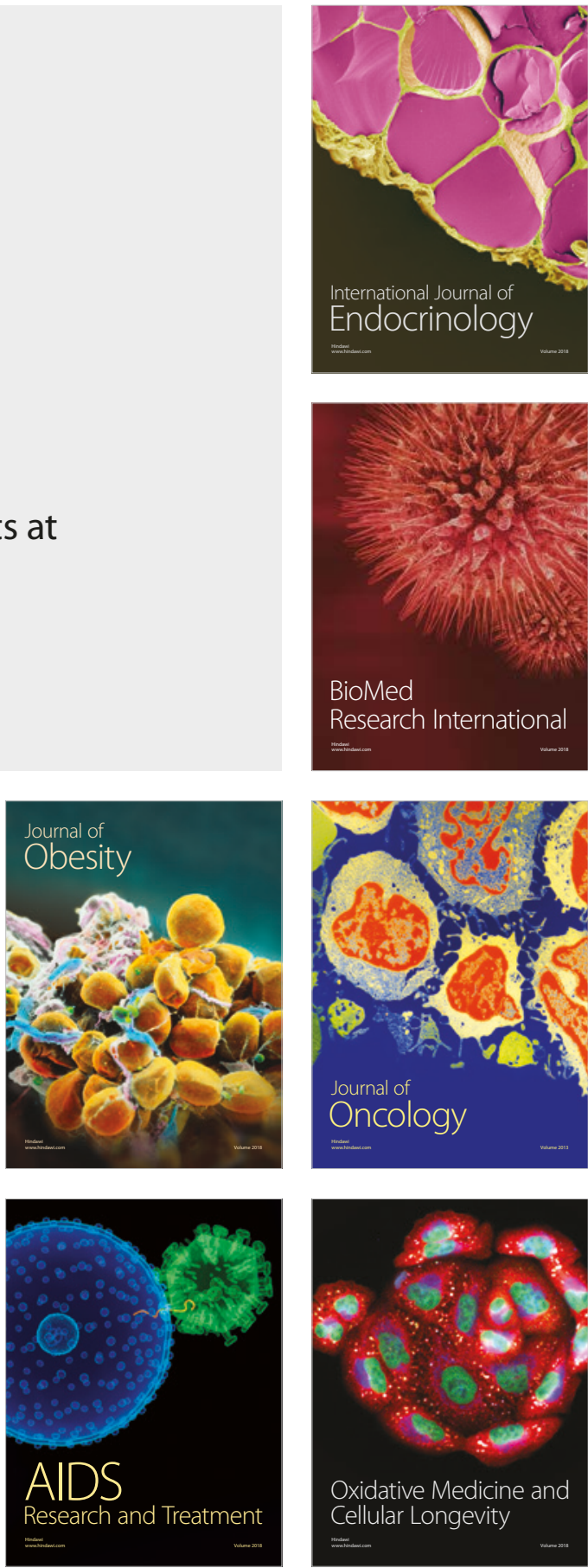